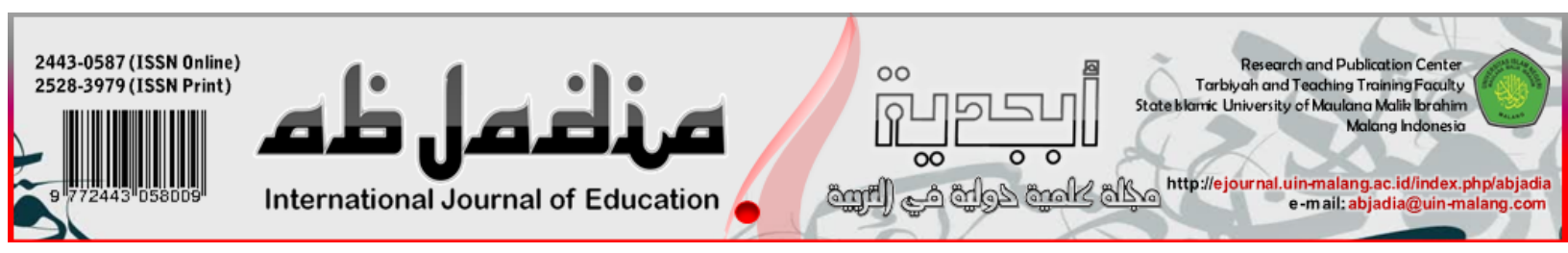

\title{
VALUE CLARIFICATION TECHNIQUE IN ENHANCING FORGIVENESS
}

\author{
Khairul Bariyyah ${ }^{1}$, Julianne Kamilia Riza ${ }^{2}$, Parid Rilo Pambudi ${ }^{3}$ \\ 1,3 Universitas Kanjuruhan Malang, Indonesia \\ ${ }^{2}$ Sekolah Tinggi Ilmu Tarbiyah Al Urwatul Wutsqo Jombang, Indonesia
}

Article History:

Received : 2019-02-01

Revised : 2019-02-10

Accepted : 2019-02-27

Published : 2019-06-30

\section{Keywords:}

Ability to Forgive Others, Value

Clarification Techniques, MTs Students

Correspondence Address:

khoirulbariyyah@unikama.ac.id

mila_faruq@yahoo.com

paridrilopambudi@gmail.com

\begin{abstract}
The ability to forgive others is a condition in which a person is able to change the negative influence and solve dissonance and distress that accompany some life events into something constructive and pleasant. One technique that can be used to improve forgiveness is the Value Clarification Technique. The purpose of this study is to find out whether value clarification techniques are effective in increasing the ability to forgive others in MTs students. The research method used was experimental research with the type of One group pretest-posttest design. The research subjects were 8th grade MTs Al-Urwatul Wutsqo Jombang which were selected by purposive sampling technique. The instruments used were the Enright Forgiveness Inventory (EFI) attitude scale, and the training guide used as training material. Data is analyzed by analysts at Wilcoxon Matched Pairs Signed Ranks Test. Based on the results of the study it can be concluded that the value clarification technique is effective to increase the ability to forgive others in MTs students. The suggestions for this research are: (1) To get maximum results in the application of value clarification techniques, the counselor is expected to pay more attention to the cultural factors possessed by the subject, (2) Further researchers are expected to further deepen the research topic on self forgiveness (self-forgiveness/intrapersonal forgiveness), which is also a matter that needs attention, in order to maximize character education activities.
\end{abstract}

\section{(C) Introduction}

Every individual is a social creature who will always interact with other people (Sherif, 2017). This interaction will run harmoniously if you can understand each other, and accept each other's advantages and disadvantages (Kawamichi et al., 2016). Many things can happen in the process of interacting with other people, one of which is the occurrence of transgressive events, namely the emergence of unpleasant experiences that can be caused by other people or by yourself (Hazel \& Mortensen, 2017). Transgressive events can cause negative emotions in the individual, such as anger, sadness, hatred, hurt, feeling insulted, jealousy, revenge, and so forth (Stephan \& Stephan, 2017).

Transgressive events can be experienced by individuals of various ages and in different situations, with different causes (Bandura, 2014). Teenagers also often experience transgressive events in their interpersonal relationships (Merrill, Srinivas, \& 
Fivush, 2017). This is mostly due to their unstable emotional condition. In this period, adolescents have the intensity of emotions that are often out of proportion (Van Liefferinge et al., 2018). When he feels a victim or perceives himself as a victim of a transgressive event, the usual reaction is anger (Adams \& Inesi, 2016). Someone who is angry will try to retaliate because of a vengeful or prolonged hostility towards the perpetrator (Frey, Pearson, \& Cohen, 2015).

Some cases often occur due to the inability of teenagers to control anger, one of them is the phenomenon of bullying, (Jan \& Husain, 2015) states that bullying usually occurs on the basis of junior revenge because they have also been victims of senior bullying before them. Not to mention the cases of student fights in our environment, almost every day we can listen to news about brawls on television and newspapers, presumably one of the causes of fights is the existence of revenge (Jäggi \& Kliewer, 2016). By reason of a high sense of solidarity the students reciprocate the treatment caused by other school students who are considered detrimental to a student, or defame their school (Mujiyati, Warto, \& Agung, 2017).

One effective way to deal with transgressive events is to practice grant forgiveness, a condition in which a person is able to change negative influences and solve dissonance and distress that accompanies some life events into constructive and pleasant things (Woodyatt, Wenzel, \& de Vel-Palumbo, 2017). In line with this statment Snyder, (Worthington et al., 2015) also states that by giving mercy, individuals can welcome new days with confidence, and create better relationships with others.

Forgiveness is a set of motivations that change one's desire to take revenge, and alleviate the urge to maintain hatred towards people who have hurt or act unfairly, and increase the urge to reconcile (Gerlsma \& Lugtmeyer, 2018). According to (Cloke, 2015), forgiveness is a decision to no longer suffer, and also to heal the heart and soul. A choice to no longer seek value in anger and hatred. This also means dismissing the desire to hurt other people or ourselves, for the events that have occurred (J. Graham, Meindl, Koleva, Iyer, \& Johnson, 2015).

Based on the results of several studies, forgiveness has been shown to significantly contribute to physical health, psychological well-being, and the quality of interpersonal relationships. Every time someone feels resentful and resentful, he is more at risk of developing health problems (Beasley, Mason, \& Smith, 2016). Great anger and hostility have been shown to have a significant relationship with decreased immune function, depression, drug abuse, and poor health conditions, high blood pressure, and heart problems (Yoo et al., 2016).

(Greenberg, 2017) show that psychologically forgiveness therapy (forgiving others) is useful for overcoming depression and anxiety for women who experience emotional violence as a result of the long-term violence of their partners. Other research results show that forgiveness is also useful as a mechanism of healing and resilience to trauma (Kurasawa, 2015). In the school setting, the ability to forgive others is also proven to be 
able to help students who are victims of bullying in dealing with the trauma they experience (Watson, Rapee, \& Todorov, 2017).

The ability to forgive others also influences happiness and individual satisfaction in interpersonal relationships (Jiang, Yue, Lu, \& Yu, 2015). In addition, forgiveness is also proven to be able to improve relationship closeness and commitment after a painful event (Zhu, 2015). If the victim is willing to forgive the offender, the relationship with the offender can be restored, but if the victim does not forgive the offender, a relationship can be broken (Pelucchi, Paleari, Regalia, \& Fincham, 2015).

In line with discussion, individuals who are willing to give mercy will have closer relations and brotherhood that are more stable than individuals who are not willing to forgive (Young, 2016). Feelings of revenge and hurt in an interpersonal relationship will potentially disrupt the stability of the relationship. Removing displeasure and the effort to forgive are important things to maintain closeness and intimate relationships with other people (K. L. Graham, Morse, O’Donnell, \& Steger, 2017). Having a healthy physical, emotional, and social will lead one towards a happier life, as stated by (Diener \& Tay, 2017) that besides being able to improve interpersonal relations, forgiving others can also improve well-being.

One technique that can be used by counselors to improve forgiveness skills for students is the Value Clarification Technique (VCT) (Neng Lin, Enright, \& Klatt, 2011). VCT is a method to help people find or realize the values underlying their behavior, feelings, ideas, and important choices that have been made (Witteman et al., 2016). In the context of this research the researcher intends to help students discover and realize the values contained in forgiveness, with the hope that after being able to realize the importance of the value of forgiveness, students will have a commitment to be more forgiving, and ultimately have forgiving behavior other people.

The Value Clarification technique was chosen because it was considered as one of the appropriate techniques for intervening in value education (Suryani, 2018). Clarification of values to develop moral values in students in the learning process emphasizes the approach in the form of analyzing the values both factual and rational by considering the pluses of existing values to the problem of values, to produce decisions about problems. the issue of moral value or conflict of moral values intelligently and critically, which contains the best value obtained through self-awareness of the students themselves, not by coercion from other parties (Adu, Ige, \& Adu, 2018).

VCT has three main stages, namely choosing, prizing, and acting (Witteman et al., 2016), which are in accordance with the stages of forgiveness, so this method is expected to be effective in increasing forgiveness of others in students. The stage of choosing / choosing to work in the cognitive domain, in this stage students will be given the opportunity to choose. In the context of the forgiveness process, the uncovering and decision phases can be taken through a voting procedure, where students are given the opportunity to choose directly, by providing alternatives, and by presenting various 
consequences of the decisions taken. The next stage is prizing / rewarding which works in the affective domain. In this stage the third forgiveness process is the work phase takes place, where students are helped to do reframing, develop empathy, and begin learning to accept the transgressive events they experience. The last step in the value clarification technique is acting. As the name suggests, this stage is in the realm of behavior, and in accordance with the last stage in the forgiveness process, which is outcome/deepening phase. In this phase individuals have found new meaning about the concept of forgiveness, and realize that forgiveness has a positive impact on their lives. Next, the individual will open himself up to always be a person who is forgiving, and make forgiveness behavior an attitude of his daily life

According to (Pieterse, de Vries, Kunneman, Stiggelbout, \& Feldman-Stewart, 2013), the purpose of the value clarification approach is a) Helping students to realize and identify their own values and other people's values, b) Helping students to be able to communicate their own values to others openly and honestly, and c) Helping students to be able to use their rational thinking abilities and emotional awareness together, in order to understand their own feelings, values, and behavior patterns.

There are a number of benefits that can be learned when a value clarification approach is applied. By using this approach, we can improve the ability of students to a) Communicate / express ideas, beliefs, values and feelings, b) empathize, c) Solve problems, d) Be assertive, e) Take decisions, and f) Have establishment (LlewellynThomas \& Crump, 2013).

Based on the background exposure of the problem, the formulation of the problem in this study is whether the value clarification technique is effective in increasing the ability to forgive others in MTs students?.

\section{[Q] Method}

The research method used in this study was experimental research with the type of One group pretest-posttest design (Creswell \& Creswell, 2017). The variable in this study consisted of the dependent variable $(y)$, namely the ability to forgive others and the independent variable $(x)$, namely the value clarification technique. The subjects in this study were 8th grade MTs al-Urwatul Wutsqo Jombang students selected by purposive sampling technique that is students who have the ability to forgive others who are low. These 8 students live in boarding schools. In this study there are 3 types of instruments used, namely, the scale of the Enright Forgiveness Inventory (EFI) is an adaptation of an inventory compiled by Robert D. Enright and Julio Rique, as well as training guides used as material in training activities and have been through expert validation or assessment from expert judgment. To answer the research problem formulation the data were analyzed by non parametric statistical analysis, namely by using Wilcoxon Matched Pairs Signed Ranks Test analysts (Rey \& Neuhäuser, 2011). 


\section{Result}

Based on the results of the study obtained several important findings. The first is that the level of ability to forgive others in students before training is in the low category. The eight research subjects have diverse backgrounds for transgressive events; the A1 subject holds a grudge against his roommate because he was accused of stealing his friend's clothes. A2 subjects had problems similar to A6, they both felt hurt after receiving unfair treatment from santri coaches. Subject A3 experienced a transgressive event after being betrayed by his closest friend, and A4 was in conflict with his father. While the A5 subject was in conflict with his senior who had woken him up by watering, and the A7 subject had recently been summoned to the counselor for fighting with an MA student, while A8 subjects were experiencing a transgressive event after being shunned by their little friend. Of the eight subjects in this study, only the A7 subjects were references from the counselor, the other seven subjects were captured using an attitude scale launched by the researcher.

The researcher then provided training to 8 subjects by applying value clarification techniques. The intervention procedure with value clarification techniques is carried out through several stages, namely: 1) The stage of choosing, which includes: Choosing freely, Choosing from various alternatives, Choosing from various alternatives after considering various consequences, 2) Stage of respect, which includes: Respect and feel happy with his choice, Willing to acknowledge choices in public, 3) Stage of action, which includes: Behaving according to choice, Repeating behavior according to choice, until finally it becomes a pattern of behavior in life. The intervention was carried out for 6 meetings with the duration of each meeting 45 minutes. Based on the results of the post test after the introduction of the value clarification technique, the following data are obtained:

Table 1. Pretest and Posttes results data ability to forgive others after the application of value clarification techniques

\begin{tabular}{|c|c|c|c|c|c|}
\hline \multirow{2}{*}{ Subject } & \multirow{2}{*}{ Gender } & \multicolumn{2}{|c|}{ Before intervention } & \multicolumn{2}{c|}{ After Intervention } \\
\cline { 3 - 6 } & & Value & Category & Value & Category \\
\hline A1 & Male & 83 & Low & 265 & High \\
\hline A2 & Female & 98 & Low & 292 & High \\
\hline A3 & Female & 64 & Low & 235 & High \\
\hline A4 & Female & 105 & Low & 247 & High \\
\hline A5 & Male & 103 & Low & 281 & High \\
\hline A6 & Female & 89 & Low & 259 & High \\
\hline A7 & Male & 149 & Medium & 308 & High \\
\hline A8 & Female & 116 & Low & 271 & High \\
\hline
\end{tabular}

Based on the explanation of the results of the above research it can be seen that all research subjects showed a positive response to the intervention provided, this can be seen from the increase in the scores achieved by the eight subjects after the training. The eight subjects had a forgiveness ability score that was in the low category before training which then increased to a high category after training. 
The test results of different abilities to forgive others through pretest and posstest also showed supportive results. When compared between pretest and posstest data, the $\mathrm{Z}$ value of $-2.521 \mathrm{~b}$ is obtained which falls on the probability of $0.012(<0.25)$, which means that $\mathrm{H} 0$ is rejected. There was a significant difference in the ability to forgive others between pretest and post-test or an increase in the ability to forgive others after the application of value clarification technique.

\section{i Discussion}

Although they have different backgrounds for transgressive events, the eight research subjects felt more or less the same psychological stress in their daily lives, both at school and at the cottage. They have feelings of hurt, hatred, and revenge against the perpetrators of this transgressive event. This information is obtained from observation, interviews, attitude scale, and additional information obtained from the counselor and coaches of the students. Some subjects were noted to have increased truancy rates, not only from school learning activities, but also from pondok diniyah activities, this indicates that the consequences of a transgressive event can cause psychological pressures that force students to take shortcuts by breaking the rules (Van Kleef, Wanders, Stamkou, \& Homan, 2015). From the results of observations and interviews, information was also obtained that some subjects seemed to tend to avoid interaction with the actors of transgressive events, and withdraw from association with their friends. This shows that transgressive events also have an influence on the quality of individual interpersonal relationships (Zhang, Ting-Toomey, Oetzel, \& Zhang, 2015).

Based on the explanation of the results of the study it was found that all research subjects showed a positive response to the intervention provided, this can be seen from the increase in the scores achieved by the eight subjects after the training. In increasing the ability to forgive others, the application of value clarification techniques in this study was carried out through three main stages, namely choosing, prizing, and acting (Witteman et al., 2016). These three stages work by involving three psychological domains, namely cognitive, affective, and behavior / behavior. This is in accordance with the 3 components of forgiveness which are also the main stages in forgiveness, namely cognitive, emotional, and behavioral (Cornish, Wade, \& Cikara, 2017). This condition causes the value clarification technique to produce effective results, because the value clarification technique uses an approach that is exactly the same as the stages possessed by the ability to forgive others, so that the results achieved by the subject are more maximal.

At the choosing stage, the stimulus given works in the realm of cognition by placing the subject on the choices that must be made. At the prizing stage, subjects are challenged to appreciate the choices that have been made, taking into account the feelings of the perpetrators of the transgressive events. Subjects were invited to reframing and develop empathy. Subjects were also asked to show that they felt happy after taking the choice to 
forgive, and dare to state it in front of group members. In the acting stage, subjects were asked to reflect on the choices they had taken and appreciated, on the events they experienced. At the same time the subjects were invited to make a commitment to be individuals who were easy to forgive others.

Clarification of values as a procedure for developing moral values in students in the learning process emphasizes approaches in the form of analyzing both factual and rational values by considering the pluses of existing values for the problem of values, to produce decisions about issues of moral value or conflict of moral values intelligently and critically, which contain the best value obtained through self-awareness of the students themselves, not by coercion from other parties (Weernink, van Til, Witteman, Fraenkel, \& IJzerman, 2018).

According to (Pieterse et al., 2013), the purpose of the value clarification approach is a) Helping students to realize and identify their own values and other people's values, b) Helping students to be able to communicate their own values to others openly and honestly, and c) Helping students to be able to use their rational thinking abilities and emotional awareness together, in order to understand their own feelings, values, and behavior patterns.

Furthermore, by providing training to increase the ability to forgive others through the Value Clarification technique, it can also help students change the negative influence and solve dissonance and distress that accompany some negative life events into constructive and pleasant things so that students can easily forgive against the mistakes of others around him (Gregg, Namekata, Louie, \& Chancellor-Freeland, 2014).

Meanwhile, as one of the values in character education, forgiveness that is embedded in students is able to form students to understand, experience, and integrate values that become the core values in the education they carry into their personalities so that the character education goals planned to shape students not only superior and also smart students both in terms of science and personality can also be realized (Berghoff, Forsyth, Ritzert, Eifert, \& Anderson, 2018).

\section{吕 Conclusion}

Based on the results of the study it can be concluded that the ability to forgive others in MTs students increases after the application of value clarification techniques or value clarification techniques is effective in increasing the ability to forgive others in MTs students.

Suggestions for research are: (1) To get maximum results in the application of value clarification techniques, the counselor is expected to pay more attention to the cultural factors possessed by the subject, in the context of this research the counselor is expected to be more active and open. This condition needs to be created so that the counselor can act as a model for students / students in order to develop a more open and active attitude, 
not only in training activities such as those carried out in this study, but more towards students' self-development goals to meet the future. (2) Further researchers are expected to further deepen the research topic. If in this study forgiveness is seen from an interpersonal perspective, it is expected that the next researcher can conduct research on self forgiveness (self-forgiveness / intrapersonal forgiveness), which is also a matter that needs attention, in order to maximize character education activities.

\section{Eibliography}

Adams, G. S., \& Inesi, M. E. (2016). Impediments to forgiveness: Victim and transgressor attributions of intent and guilt. Journal of Personality and Social Psychology, 111(6), 866.

Adu, E. O., Ige, O. A., \& Adu, K. O. (2018). Action Learning, Value Clarification, Conventional Lecture Method, and Secondary School Students' Attitude to Information and Communication Technology Concepts in Social Studies in Rural Learning Ecologies. In New Media for Educational Change (pp. 11-26). Springer.

Bandura, A. (2014). Social cognitive theory of moral thought and action. In Handbook of moral behavior and development (pp. 69-128). London: Psychology Press.

Beasley, A., Mason, W., \& Smith, E. (2016). Inferring emotions and self-relevant domains in social media: Challenges and future directions. Translational Issues in Psychological Science, 2(3), 238.

Berghoff, C. R., Forsyth, J. P., Ritzert, T. R., Eifert, G. H., \& Anderson, D. A. (2018). Evaluation of the contribution of values clarification to a brief mindfulness meditation intervention for anxiety. Journal of Clinical Psychology, 74(9), 1387-1402. https:/ / doi.org/10.1002/jclp.22610

Cloke, K. (2015). Designing Heart-Based Systems to Encourage Forgiveness and Reconciliation in Divorcing Families. Family Court Review, 53(3), 418-426.

Cornish, M. A., Wade, N. G., \& Cikara, A. (2017). Self-Forgiveness in individual psychotherapy: Therapeutic models and counseling outcomes. In Handbook of the psychology of selfforgiveness (pp. 163-177). Springer.

Creswell, J. W., \& Creswell, J. D. (2017). Research Design: Qualitative, Quantitative, and Mixed Methods Approaches. Thousand Oaks, CA: Sage Publications.

Diener, E., \& Tay, L. (2017). A scientific review of the remarkable benefits of happiness for successful and healthy living. Happiness, 90.

Frey, K. S., Pearson, C. R., \& Cohen, D. (2015). Revenge is seductive, if not sweet: Why friends matter for prevention efforts. Journal of Applied Developmental Psychology, 37, 25-35. https://doi.org/10.1016/J.APPDEV.2014.08.002

Gerlsma, C., \& Lugtmeyer, V. (2018). Offense type as determinant of revenge and forgiveness 
after victimization: Adolescents' responses to injustice and aggression. Journal of School Violence, 17(1), 16-27.

Graham, J., Meindl, P., Koleva, S., Iyer, R., \& Johnson, K. M. (2015). When values and behavior conflict: Moral pluralism and intrapersonal moral hypocrisy. Social and Personality Psychology Compass, 9(3), 158-170.

Graham, K. L., Morse, J. L., O’Donnell, M. B., \& Steger, M. F. (2017). Repairing meaning, resolving rumination, and moving toward self-forgiveness. In Handbook of the psychology of self-forgiveness (pp. 59-72). Springer.

Greenberg, L. S. (2017). Emotion-focused therapy of depression. Person-Centered E Experiential Psychotherapies, 16(2), 106-117.

Gregg, J. A., Namekata, M. S., Louie, W. A., \& Chancellor-Freeland, C. (2014). Impact of values clarification on cortisol reactivity to an acute stressor. Journal of Contextual Behavioral Science, 3(4), 299-304.

Hazel, S., \& Mortensen, K. (2017). The classroom moral compass-participation, engagement and transgression in classroom interaction. Classroom Discourse, 8(3), 214-234.

Jäggi, L., \& Kliewer, W. (2016). “Cause That's the Only Skills in School You Need” A Qualitative Analysis of Revenge Goals in Poor Urban Youth. Journal of Adolescent Research, 31(1), 32 58.

Jan, A., \& Husain, S. (2015). Bullying in Elementary Schools: Its Causes and Effects on Students. Journal of Education and Practice, 6(19), 43-56.

Jiang, F., Yue, X., Lu, S., \& Yu, G. (2015). Can you forgive? It depends on how happy you are. Scandinavian Journal of Psychology, 56(2), 182-188.

Kawamichi, H., Sugawara, S. K., Hamano, Y. H., Makita, K., Kochiyama, T., \& Sadato, N. (2016). Increased frequency of social interaction is associated with enjoyment enhancement and reward system activation. Scientific Reports, 6, 24561. Retrieved from https:// doi.org/10.1038/srep24561

Kurasawa, F. (2015). The Healing of Wounds: Forgiveness as a Cultural Practice. In Culture, Society, and Democracy (pp. 135-168). Routledge.

Llewellyn-Thomas, H. A., \& Crump, R. T. (2013). Decision support for patients: values clarification and preference elicitation. Medical Care Research and Review, 70(1_suppl), 50S795 .

Merrill, N., Srinivas, E., \& Fivush, R. (2017). Personal and intergenerational narratives of transgression and pride in emerging adulthood: Links to gender and well-being. Applied Cognitive Psychology, 31(2), 119-127.

Mujiyati, N., Warto, W., \& Agung, L. (2017). The Strategies to Improve Social Solidarity of 
Senior High School Students through History Module Based on Problems. Journal of Education and Learning (EduLearn), 11(2), 130-137.

Neng Lin, W., Enright, R., \& Klatt, J. (2011). Forgiveness as character education for children and adolescents. Journal of Moral Education, 40(2), 237-253.

Pelucchi, S., Paleari, F. G., Regalia, C., \& Fincham, F. D. (2015). Self-forgiveness in romantic relationships: 2. Impact on interpersonal forgiveness. Family Science, 6(1), 181-190.

Pieterse, A. H., de Vries, M., Kunneman, M., Stiggelbout, A. M., \& Feldman-Stewart, D. (2013). Theory-informed design of values clarification methods: a cognitive psychological perspective on patient health-related decision making. Social Science E Medicine, 77, 156163.

Rey, D., \& Neuhäuser, M. (2011). Wilcoxon-signed-rank test. In International encyclopedia of statistical science (pp. 1658-1659). Springer.

Sherif, M. (2017). Social interaction: Process and products. New York: Routledge.

Stephan, W. G., \& Stephan, C. W. (2017, December 13). Intergroup Threat Theory. The International Encyclopedia of Intercultural Communication. https:/ / doi.org/ doi:10.1002/9781118783665.ieicc0162

Suryani, N. (2018). VCT (Value Clarification Technique) Learning Model Application to Improve Historical Value Understanding. Historia: Jurnal Pendidik Dan Peneliti Sejarah, 11(2), 198-217.

Van Kleef, G. A., Wanders, F., Stamkou, E., \& Homan, A. C. (2015). The social dynamics of breaking the rules: antecedents and consequences of norm-violating behavior. Current Opinion in Psychology, 6, 25-31.

Van Liefferinge, D., Sonuga-Barke, E., Danckaerts, M., Fayn, K., Van Broeck, N., \& van der Oord, S. (2018). Measuring child and adolescent emotional lability: How do questionnaire-based ratings relate to experienced and observed emotion in everyday life and experimental settings? International Journal of Methods in Psychiatric Research, 27(3), e1720. https://doi.org/10.1002/mpr.1720

Watson, H., Rapee, R., \& Todorov, N. (2017). Forgiveness reduces anger in a school bullying context. Journal of Interpersonal Violence, 32(11), 1642-1657.

Weernink, M. G. M., van Til, J. A., Witteman, H. O., Fraenkel, L., \& IJzerman, M. J. (2018). Individual Value Clarification Methods Based on Conjoint Analysis: A Systematic Review of Common Practice in Task Design, Statistical Analysis, and Presentation of Results. Medical Decision Making, 0272989X18765185.

Witteman, H. O., Scherer, L. D., Gavaruzzi, T., Pieterse, A. H., Fuhrel-Forbis, A., Chipenda Dansokho, S., ... Col, N. F. (2016). Design features of explicit values clarification methods: a systematic review. Medical Decision Making, 36(4), 453-471. 
Woodyatt, L., Wenzel, M., \& de Vel-Palumbo, M. (2017). Working through psychological needs following transgressions to arrive at self-forgiveness. In Handbook of the psychology of selfforgiveness (pp. 43-58). Springer.

Worthington, E. L., Lavelock, C., vanOyen Witvliet, C., Rye, M. S., Tsang, J.-A., \& Toussaint, L. (2015). Measures of forgiveness: Self-report, physiological, chemical, and behavioral indicators. In Measures of personality and social psychological constructs (pp. 474-502). Elsevier.

Yoo, Y.-G., Lee, D.-J., Lee, I.-S., Shin, N., Park, J.-Y., Yoon, M.-R., \& Yu, B. (2016). The effects of mind subtraction meditation on depression, social anxiety, aggression, and salivary cortisol levels of elementary school children in South Korea. Journal of Pediatric Nursing, 31(3), e185-e197.

Young, L. A. (2016). Rational choice theory and religion: Summary and assessment. New York: Routledge.

Zhang, Q., Ting-Toomey, S., Oetzel, J. G., \& Zhang, J. (2015). The Emotional Side of Forgiveness: A Cross-Cultural Investigation of the Role of Anger and Compassion and Face Threat in Interpersonal Forgiveness and Reconciliation. Journal of International and Intercultural Communication, 8(4), 311-329.

Zhu, H. (2015). Social support and affect balance mediate the association between forgiveness and life satisfaction. Social Indicators Research, 124(2), 671-681.

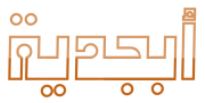

